\title{
Recycling of Waste Materials for Asphalt Concrete and Bitumen: A Review
}

\author{
Md Tareq Rahman*(D), Abbas Mohajerani ${ }^{\mathbb{D}}$ and Filippo Giustozzi $(\mathbb{D}$ \\ School of Engineering, RMIT University, Melbourne 3000, Australia; abbas.mohajerani@rmit.edu.au (A.M.); \\ filippo.giustozzi@rmit.edu.au (F.G.) \\ * Correspondence: md.tareq.rahman@student.rmit.edu.au
}

Received: 21 February 2020; Accepted: 24 March 2020; Published: 25 March 2020

\begin{abstract}
Waste management has become an issue of increasing concern worldwide. These products are filling landfills and reducing the amount of livable space. Leachate produced from landfills contaminates the surrounding environment. The conventional incineration process releases toxic airborne fumes into the atmosphere. Researchers are working continuously to explore sustainable ways to manage and recycle waste materials. Recycling and reuse are the most efficient methods in waste management. The pavement industry is one promising sector, as different sorts of waste are being recycled into asphalt concrete and bitumen. This paper provides an overview of some promising waste products like high-density polyethylene, marble quarry waste, building demolition waste, ground tire rubber, cooking oil, palm oil fuel ash, coconut, sisal, cellulose and polyester fiber, starch, plastic bottles, waste glass, waste brick, waste ceramic, waste fly ash, and cigarette butts, and their use in asphalt concrete and bitumen. Many experts have investigated these waste materials and tried to find ways to use this waste for asphalt concrete and bitumen. In this paper, the outcomes from some significant research have been analyzed, and the scope for further investigation is discussed.
\end{abstract}

Keywords: asphalt concrete; recycling; waste materials; environmental sustainability; advanced materials

\section{Introduction}

A million tons of waste are generated each day around the world. Landfills are used to dump most of this waste. Between 2014 and 2015, Australia produced over 27 million tons of waste [1]. These findings indicate a 6 million ton increase in landfill waste since 2007 [2]. Of the 27 million tons of waste disposed of in 2014-2015, approximately 6.5 million tons were of municipal waste, 13 million tons were of commercial and industrial waste, and 7.1 million tons were of construction and demolition waste [1]. Modern and comfortable lifestyles and innovations in technology, along with industrialization, have increased the quantity and variety of waste being generated, resulting in a severe crisis for proper waste disposal systems [3]. Conventional waste disposal methods are not always efficient and environmentally friendly. Incineration is one popular waste disposal method. However, from research it has been found that the emissions of $\mathrm{CO}_{2}$ from incinerators are higher than those for coal, oil, or gas-propelled power plants. Incinerators produce 210 different types of toxic compounds, including mercury, fluorides, sulfuric acid, nitrous oxide, hydrogen chloride, and cadmium [4].

The world's population is increasing, depleting natural resources. Over recent decades, the retrieval of materials and energy from waste materials has received attention, with the aim of finding a sustainable solution to reduce the exploitation of natural resources and reduce landfill usage, [5]. Sustainability is a thriving field in this millennium [6]. The world is in needs to conserve its resources and determine innovative ways to recycle waste to ensure sustainability [7]. The concept of recycling 
waste has created a large sector for research. Researchers from various organizations have explored different types of waste materials with green material technologies to reduce environmental impacts and recycle waste in the construction industry [4,8-10].

Roads and highways are a critical sector for asset management worldwide. Most highways are flexible in type [11]. Australia has over 350,000 km of surfaced road, and produces over 10 million tons of asphalt concrete per annum [12,13]. Aggregates form up to 95\% of asphalt concrete. Therefore, the introduction of alternative aggregates into the production of asphalt concrete and bitumen can help ease the pressure on the world's landfills and help create sustainable practices for upcoming major road projects around the globe.

\section{Asphalt Concrete}

Flexible pavement is a widely used type of pavement. Statistics show that $95 \%$ of the total highways of the world are made of flexible pavement $[7,14]$. The type of binder differentiates the two most significant pavement types, which are flexible pavement and rigid pavement. In the case of rigid pavement, Portland cement is used as the binder, and bitumen is used as a binder for flexible pavement. Asphalt concrete is a mixture of aggregates and bitumen. The asphalt concrete mix can be classified into two major categories based on the gradation of the aggregates: hot mix asphalt (HMA) and stone mastic asphalt (SMA). Figure 1 shows the basic structure of a typical asphalt pavement.

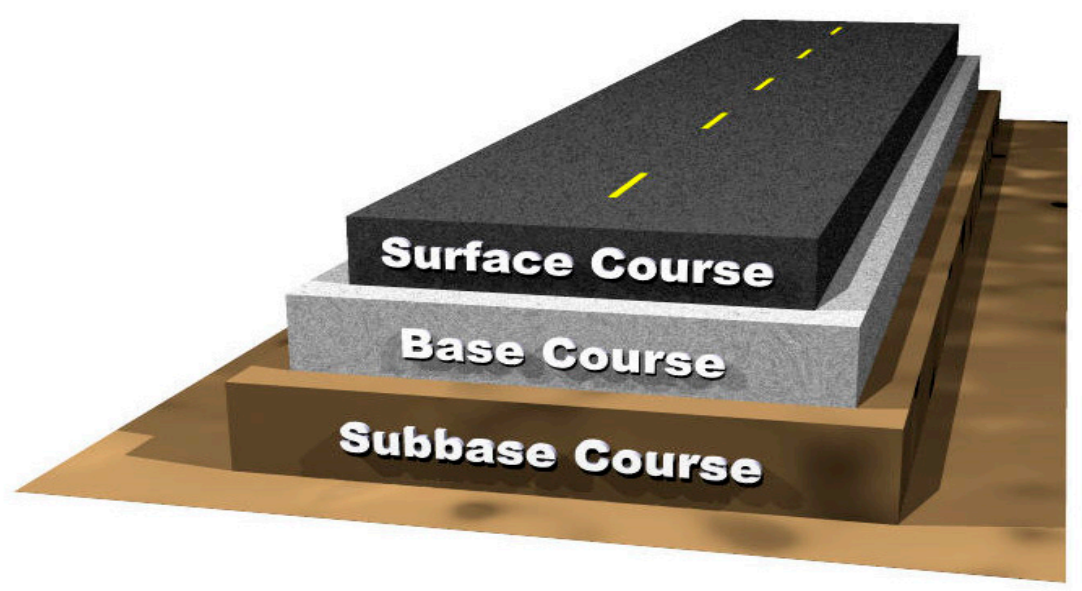

Figure 1. Typical structure of asphalt pavement [15].

\subsection{Hot Mix Asphalt (HMA)}

Hot mix asphalt (HMA) can be dense- or open-graded. As the name suggests, dense-graded HMA has a lower void ratio compared with open-graded HMA. Dense-graded HMA contains a large variety of particle sizes to spread through the asphalt concrete mix effectively. Furthermore, dense-graded HMA suits all traffic condition types and is the most commonly used type of asphalt concrete around the world [16]. Open-graded HMA is typically used in drainage layers due to its higher void ratio, which allows the mix to be more permeable [16,17].

\subsection{Stone Mastic Asphalt (SMA)}

Stone mastic asphalt is a gap-graded HMA, and is commonly used throughout Europe [17]. The aggregates used in SMA mixes are often of higher quality compared with the aggregates used for standard HMA mixes due to their superior physical and mechanical properties, which are required for the stone-to-stone contact structure. SMA's high content of coarse aggregates creates high rutting resistance and improves the longevity of the structure [18]. 


\subsection{Advantages and Disadvantages of Different Type of Asphalt}

A comparative image of HMA and SMA is shown in Table 1. Gradation may vary among different types of asphalt, but the essential ingredients are mostly the same. In the case of HMA, open-graded aggregates and bitumen are used. On the other hand, gap-graded aggregate, fibers, and bitumen are used in SMA [19]. Figure 2 exhibits the structural texture of SMA and HMA.

Table 1. Advantages and disadvantages of HMA and SMA.

\begin{tabular}{|c|c|c|}
\hline Type of Asphalt & Advantages & Disadvantages \\
\hline Hot mix asphalt (HMA) & $\begin{array}{l}\text { Low cost } \\
\text { Effective in all traffic conditions }\end{array}$ & $\begin{array}{l}\text { Lower rutting resistance } \\
\text { Shorter service life } \\
\text { Lesser quality aggregates used }\end{array}$ \\
\hline Stone mastic asphalt (SMA) & $\begin{array}{l}\text { Long service life } \\
\text { High resistance to deformation } \\
\text { Increased fatigue testing life } \\
\text { Noise-reductive properties } \\
\text { Decreased water spray when raining }\end{array}$ & $\begin{array}{l}\text { Low skid resistance } \\
\text { High cost } \\
\text { Increased risk of flat spots occurring } \\
\text { due to the SMA design procedure }\end{array}$ \\
\hline
\end{tabular}

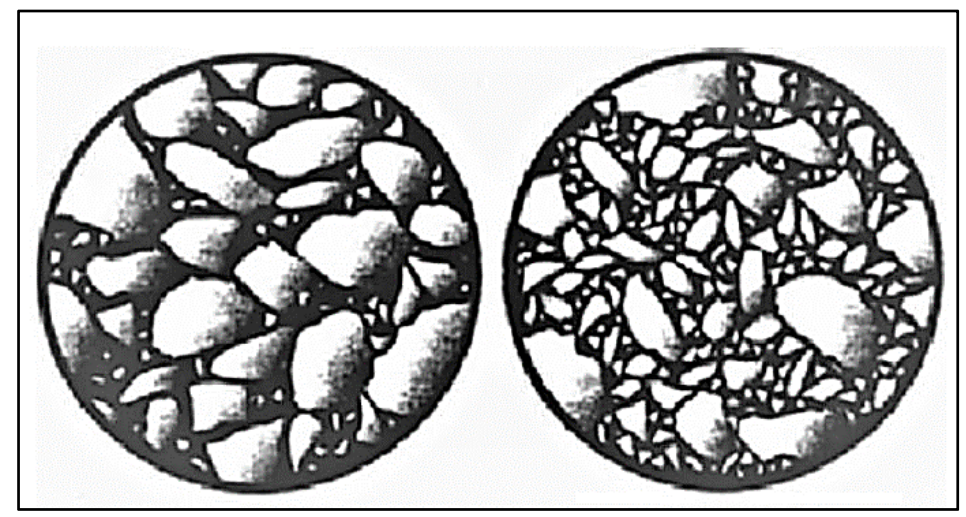

Figure 2. The structural texture of SMA (on the left) and hot dense asphalt (on the right).

\section{Bitumen}

Bitumen is a viscoelastic complex hydrocarbon that is black or brown. Although there are a few natural sources of bitumen available, bitumen is generally sourced from crude oil refineries [20]. Due to its waterproof and viscoelastic nature, bitumen is used as the binder for the construction of flexible pavement all over the world. Bitumen can be classified in three ways: through penetration grade, performance grade, or viscosity. Nowadays, bitumen classification based on viscosity grade is gaining popularity. The available types according to the Australian Standard (with a typical viscosity of bitumen of $60{ }^{\circ} \mathrm{C}$ ) for the construction of flexible pavements, with the exception of the polymer-modified bitumen (PMB) class), are provided in Figure 3 [21].

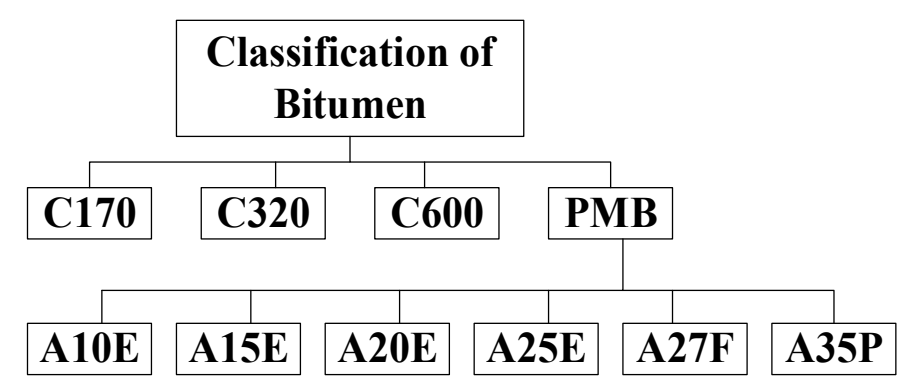

Figure 3. Classification of bitumen according to the Australian Standard for the construction of pavements. 
Around the world, researchers are working to improve the properties of these materials to ensure sustainability in the pavement construction sector $[7,20,22]$. The recycling of waste materials for use in asphalt is recognized as a very efficient method, as it improves the pavement quality, and, at the same time, helps to manage and recycle different waste products [7]. Many researchers have investigated the use of different waste materials in bitumen. Plastic and polymer-based modifiers have been used extensively for a long time. Many industries have adopted plastic rubber and polymer-modified bitumen for the construction of roads [22-24]. In contrast, many researchers have investigated the use of regular household residues like waste cooking oil in bitumen. In some cases, they have recommended an optimum amount of waste cooking oil in bitumen of up to 5\% (by weight) to ensure that any resultant compromise in the performance is minimized [22,25]. Intending to achieve better aging resistance, researchers have used palm oil fuel ash (POFA) to modify bitumen and found that POFA in bitumen can work as a rejuvenator for the binder $[22,26,27]$. Different types of fiber have been used in construction materials to alleviate the global waste management issue [28]. Several studies have found that fiber can improve the performance of bitumen [28-31]. Researchers have investigated the use of synthetic fibers like polymer fiber, steel fiber, and carbon fibers in asphalt concrete [28]. It has been found that carbon fiber can improve the electrical properties of asphalt but compromise the mechanical performance of asphalt concrete, while steel fiber improves the stability of asphalt [32,33]. Industry uses cellulose fiber to reduce binder drain-off during the transportation of the mix from the plant to the construction site $[34,35]$. As cigarette butt filters are made up of cellulose acetate-based fiber, they could represent a potential replacement for the natural cellulose fiber used in stone mastic asphalt. Recycling suitable waste in bitumen in a proper manner is a sustainable way to contribute to solving the worldwide waste management problem [36].

\section{Use of Waste Materials in Asphalt Mix and Bitumen}

Waste materials like plastic, marble quarry waste, building demolition waste, ground tire rubber, waste cooking oil, palm oil fuel ash, coconut, sisal, cellulose, polyester fibers, starch, plastic bottle, waste glass, waste brick, waste ceramic, waste fly ash, and cigarette butts have been reviewed, and methods of recycling in asphalt concrete and bitumen have been discussed. The following sections have been covered in the review of each materials.

(1) Selection of waste material.

(2) Source, characteristics, and common use.

(3) Method of recycling in asphalt concrete and bitumen.

(4) Discussion on the performance of modified asphalt concrete and bitumen prepared with waste materials.

\subsection{Plastic Waste}

Plastic is among the top waste items worldwide. Plastic waste comes in many forms. Common sources of plastic waste are plastic bags, bottles, cups, and straws. Plastic is a polymer-based material which is non-biodegradable. Due to a low manufacturing cost, convenience in carrying and storage, and waterproof nature, plastic has been extensively used around the globe as a household item.

Different types of plastic waste have been used in asphalt as additives. A study was carried out in Turkey to investigate the effect of high-density polyethylene (HDPE) modified binder in hot mix asphalt (HMA). HDPE was mixed with the bitumen content at proportions of $4 \%-6 \%$ and $8 \%$ (by weight of optimum bitumen content) [37]. Results of the prepared sample showed increased Marshall stability, Marshall quotient (MQ), and flow. When HDPE-modified binder is used in asphalt mix, resistance against permanent deformation increases, and at the same time, the process helps in recycling plastic waste. Research work in Saudi Arabia has reported that an increased level of industrialization and fast urbanization led to an increase in solid plastic waste. Authors investigated the effect of different types of plastic waste, including HDPE, in asphalt binders. Results showed an increase 
in resilience modulus, and a model indicated improvement in rutting and fatigue performance [38]. The difference between the various types of polymers like polyethylene, polypropylene, polyvinyl chloride, styrene-butadiene block copolymer, and styrene-isoprene block copolymer relates to the manufacturing process through polymerization. Each type of polymers stand alone in properties like hardness, viscosity, transparency, temperature susceptibility, color, and type of additive used. Table 2 shows the advantages and disadvantages of different types of polymer plastic in the asphalt binder.

Table 2. Characteristics of polymers used to modify asphalt binders [39].

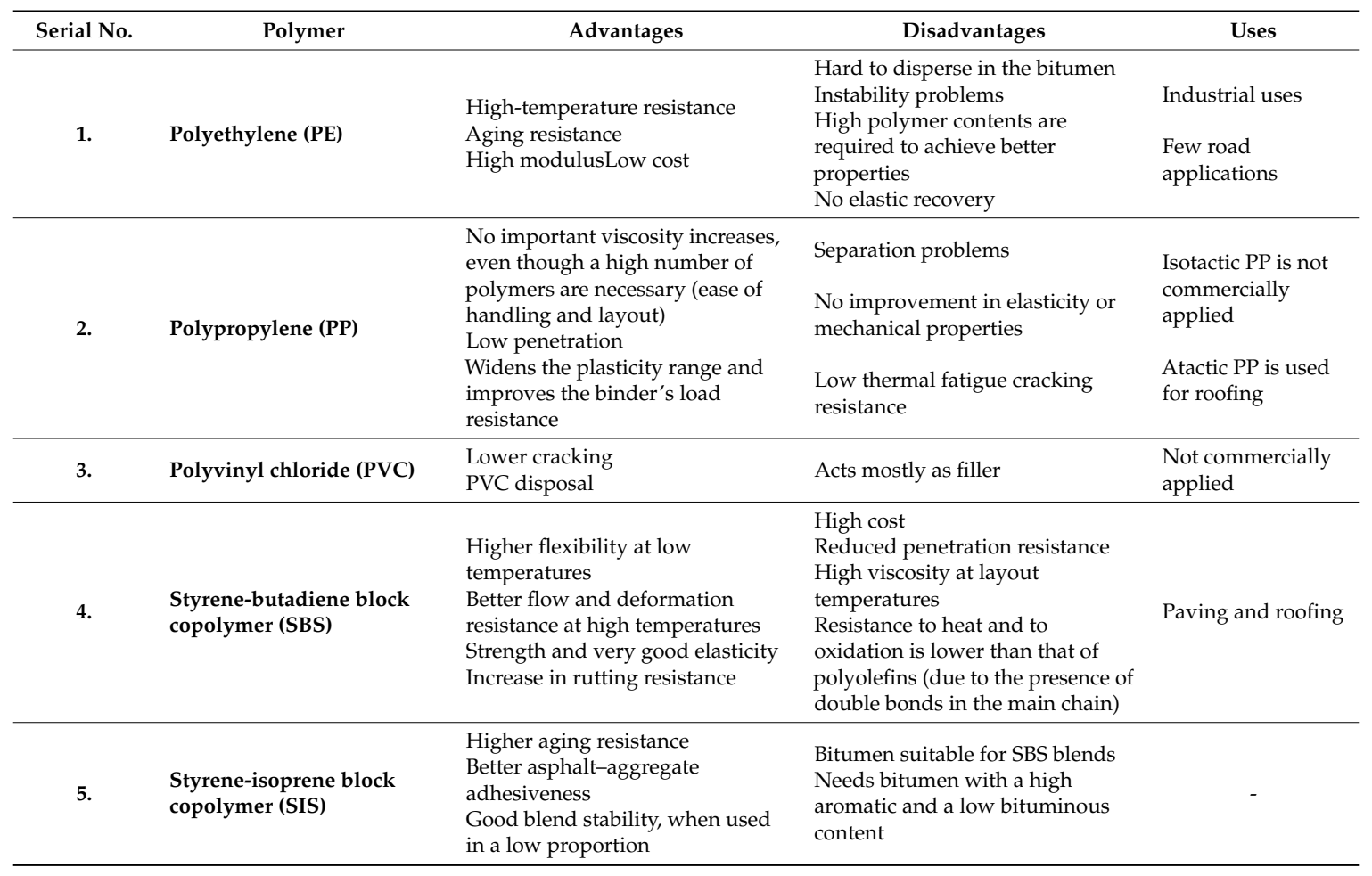

An artificial neural network study and as multiple linear regression analysis were carried out, aiming to predict permanent deformation of HDPE-modified asphalt mix. The model showed that up to $7 \%$ addition of HDPE waste materials in asphalt mixture reduced the final strain of the mixture and reduced permanent deformation under dynamic loading conditions [40].

Plastic bottles are a ubiquitous household item, and waste plastic is being dumped into landfills every day. Researchers have found that this waste has the potential to be used as a secondary aggregate [41]. The economic issue of polymer-modified asphalt mixture led a team of researchers in Malaysia to determine the effect of incorporating waste plastic bottles into stone mastic asphalt (SMA). Plastic bottles containing polyethylene terephthalate (PET) were mixed with SMA at several differing percentages. The engineering properties of SMA mixed with PET were investigated, and results were statistically analyzed. The results indicated a significant positive effect on the properties of the SMA mix [42]. Recently, another group of research enthusiasts prepared asphalt samples with $1 \%$ of waste plastic derived from PET bottles; they concluded their research with success, and they proved that waste bottles could be recycled in the construction of flexible pavement as aggregates [43]. In this research the types of sample were asphalt mixture with $5 \%$ glass, $5 \%$ plastic, $2.5 \%$ glass and $2.5 \%$ plastic; $4 \%$ plastic and $1 \%$ glass; and $1 \%$ plastic and $4 \%$ glass. Marshall stability and flow results showed an excellent prospects using $5 \%$ plastic in asphalt concrete. The adapted results are given in Table 3. 
Table 3. Marshall stability and flow results of the asphalt prepared with glass and plastic [44].

\begin{tabular}{ccccc}
\hline \multirow{2}{*}{ Sample Type } & \multicolumn{2}{c}{ Waste Materials Used } & \multirow{2}{*}{ Marshall Stability (kN) } & \multirow{2}{*}{ Flow (mm) } \\
\cline { 2 - 3 } & Glass & Plastic & & \\
\hline Control & $0 \%$ & $0 \%$ & 13.42 & 5.64 \\
Glass & $5 \%$ & $0 \%$ & 6.67 & 5.92 \\
Plastic & $0 \%$ & $5 \%$ & 14.66 & 5.92 \\
Glass + Plastic Type 1 & $2.5 \%$ & $2.5 \%$ & 11.56 & 5.61 \\
Glass + Plastic Type 2 & $1 \%$ & $4 \%$ & 14.81 & 6.26 \\
Glass + Plastic Type 3 & $4 \%$ & $1 \%$ & 11.24 & 4.08 \\
\hline
\end{tabular}

\subsection{Quarry Waste}

Quarries in different parts of the world are generating large quantities of waste. Mine exploration and extraction of minerals and valuable stones from quarries require digging and blasting, resulting in waste materials and recoverable aggregates. Aggregates from quarries possess very similar properties and appearance to conventional aggregates. In Turkey, industrial waste from marble quarries was proven useful for asphalt pavement by researchers from Afyon Kocatepe Üniversity. Increased demand for aggregate for the asphalt industry and deterioration of the general texture of the Earth's surface due to the quest for new sources motivated them to use aggregates produced from a marble quarry. During the study, researchers compared aggregates produced as waste from a homogenous marble and andesite quarry with the standard aggregates already in use for the asphalt pavement industry. The results of this research show that the physical properties of the aggregates are similar to the standard aggregates. These aggregates can be used for the construction of asphalt pavement suitable for light to medium traffic conditions [44]. The mining sector produces many waste products. These wastes can be turned into resources by proper innovation and processing methods. Construction of roads and highways require a large amount of aggregates. Conventional granite and basalt aggregates are expensive, and many countries of the world rely on importing these aggregates for their road construction. In India, limestone mining waste was processed and reformed to different sizes according to the gradation table. Asphalt mix samples were prepared by replacing up to $50 \%$ of conventional basalt aggregates with the aggregates obtained from mining waste. All the samples fulfilled Marshall design parameters for low-volume roads [45]. Figure 4 shows quarry waste and conventional aggregate for a visual comparison.
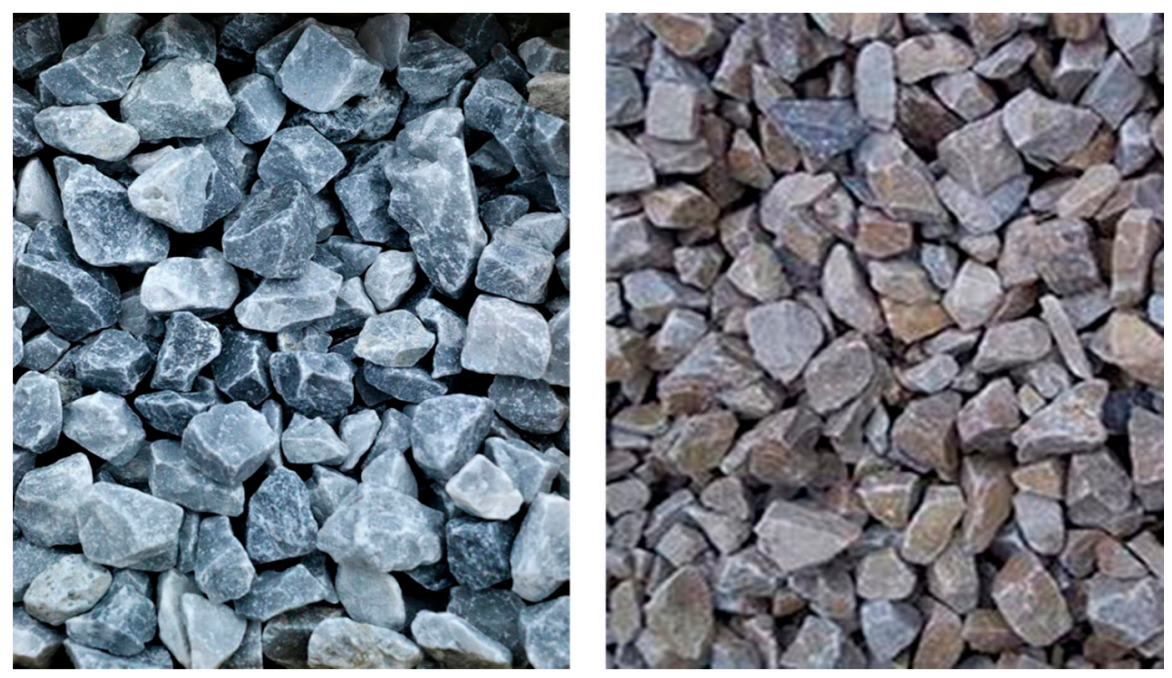

Figure 4. Quarry waste (left) and traditional aggregate (right). 


\subsection{Building Demolition Waste}

Demolished buildings generate a significant amount of waste each day, as $90 \%$ of this waste is disposed of in landfills [46]. A study in Kuwait showed the potential feasibility of demolished building waste for use in aggregates. In this study, Marshall samples were prepared with aggregates obtained from demolition waste. All samples passed the standard requirements based on laboratory investigations. In Spain, researchers evaluated and investigated laboratory and in situ mechanical properties of non-selected recycled aggregates from building demolition waste. They used this waste as an unbound aggregate for the base and sub-base layer of the pavement. Mechanical performances of the road were within acceptable limits [47]. In order to reduce pollution and the burden on landfills, a potential solution could be the recycling of demolition waste for construction material for roads, giving a second life to raw materials [48].

\subsection{Ground Tire Rubber}

Several research works have been carried out to utilize ground tire rubber in asphalt pavements. One significant study used ground tire rubber (GTR) produced in Taiwan in the production of stone mastic asphalt (SMA). When the rubber was used, no fiber was needed to stop drain-down. The results in Figure 5 show that at $60^{\circ} \mathrm{C}$, the rutting resistance of the samples was better than that of conventional SMA mix [49]. SMA samples were prepared with aggregates with a maximum of $13 \mathrm{~mm}$ (SMA 13) and maximum of $19 \mathrm{~mm}$ (SMA 19). Researchers have also studied ground tire rubber because of the increase in the number tires being dumped into landfills each day [50]. A recent study indicated that the addition of ground tire rubber in asphalt binder enhanced high-temperature properties [51,52]. Pouranian et al. (2020) investigated environmental concerns with respect to the recycling of crumb rubber in bitumen and found that emissions could be reduced with the use of additives in warm mix asphalt (WMA) [53]. Ding et al. (2019) utilized crumb rubber as the rejuvenator for reclaimed asphalt concrete (RAP) and observed improved low-temperature performances [54].

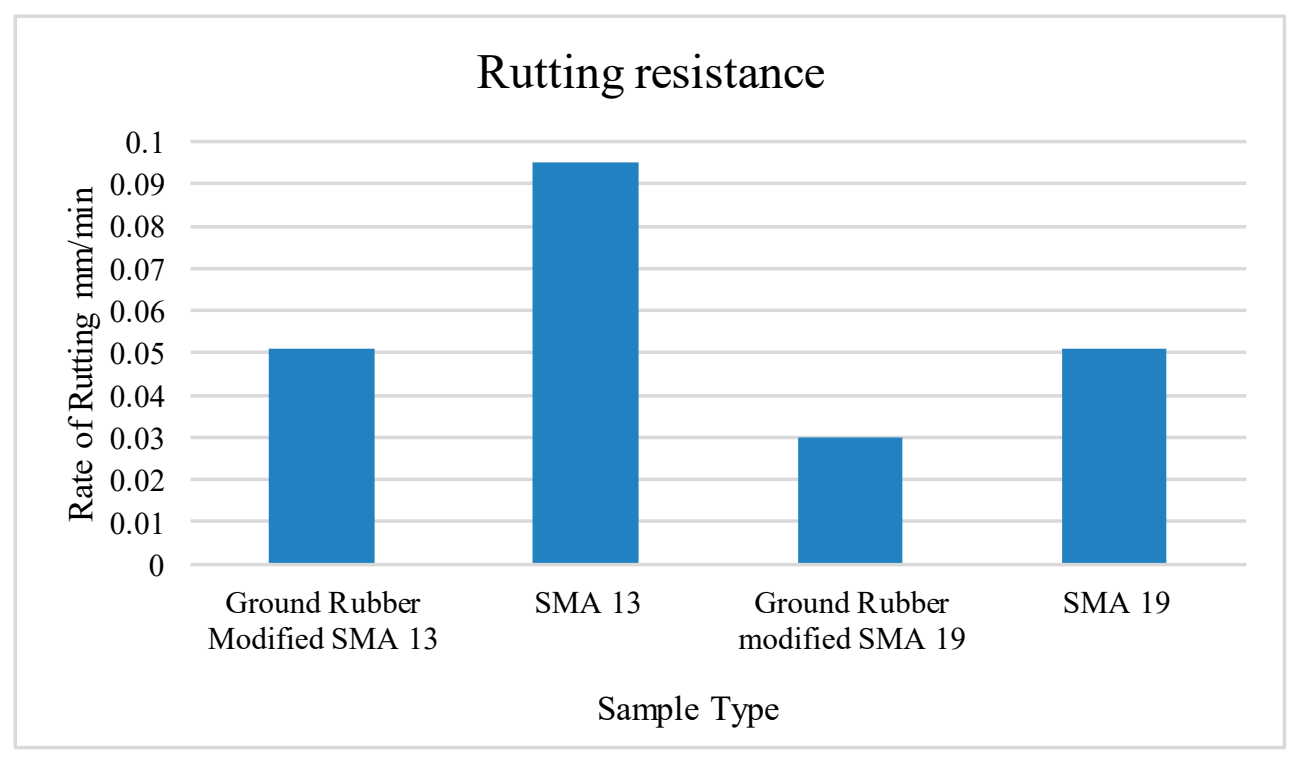

Figure 5. Rate of rutting for SMA modified with ground rubber [49].

\subsection{Waste Cooking Oil and Palm Oil Fuel Ash}

Waste cooking oil is a prevalent type of waste product. Households and restaurants generate a large amount of burnt cooking oil. Hence, the management of used cooking oil is an environmental issue. Wastes like burnt cooking oil and palm oil fuel ash can be used in asphalt mix, according to research carried out in Malaysia. Researchers modified bitumen with waste cooking oil, crumb 
rubber, and palm oil fuel ash with bitumen 60/70 (penetration grade), and compared the binder with neat bitumen. The selection of the materials and the blending process of the bitumen is shown in Figure 6 [22]. The blending procedure was performed at $120^{\circ} \mathrm{C}$ for 2 hours at $900 \mathrm{rpm}$. The result showed an increase in viscosity of the modified binder and improved penetration and rheological properties, making it a suitable binder for asphalt concrete, as shown in Figure 7.

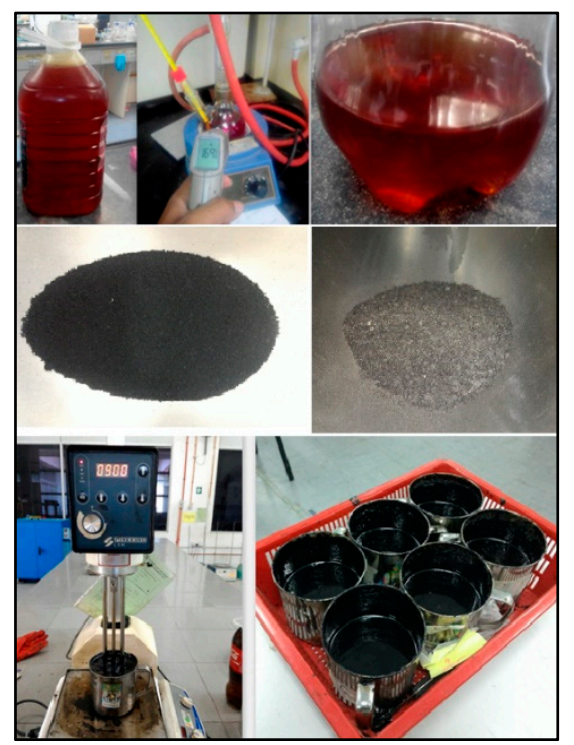

Figure 6. Asphalt binder (bottom right) modified with waste cooking oil (top), crumb rubber (middle left), palm oil fuel ash (middle right), and the blending process (bottom left) [22].

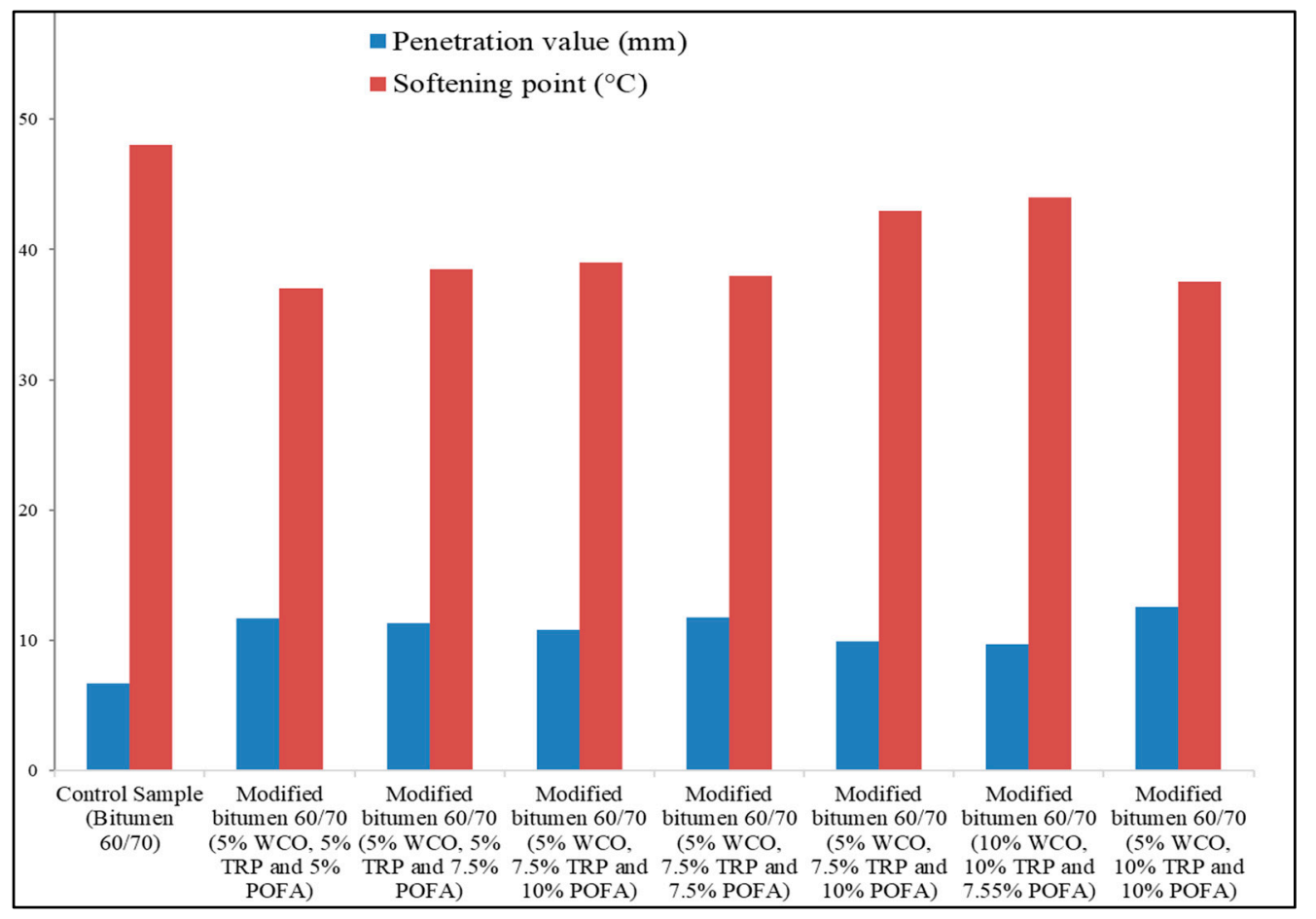

Figure 7. Physical test results of the asphalt modified with waste cooking oil (WCO), tire rubber powder (TRP), and palm oil fuel ash (POFA) [22]. 


\subsection{Coconut, Sisal, Cellulose, and Polyester Fibers}

Coconuts are very common in the tropical regions. Discarded coconut has been recycled for use in many manufactured materials. Coconut shells and fibers have recently been adopted in the asphalt pavement industry. Researchers in Malaysia explored the effect of asphalt mix, where aggregates were replaced by coconut shells. These samples contained coconut shell content of $5 \%, 10 \%$, and $15 \%$ as aggregates. At the same time, coconut fibers were added in the mix, representing $0.3 \%$ and $0.5 \%$ by weight. Additives were treated by $\mathrm{NaOH}$ before the preparation of the asphalt mix to reduce the water absorption property. The result showed better resilient modulus under a temperature of $25^{\circ} \mathrm{C}$ when $10 \%$ coconut shell aggregate was added [55,56]. In Brazil, coconut, sisal, cellulose, and polyester fibers were used to prepare stone mastic asphalt (SMA) mix. Figure 8 shows the coconut powder, which can be used as fiber for asphalt concrete. In this mixture the amount of bituminous content was higher; hence it was necessary to use fibers to prevent drain-down. Coconut-, sisal-, cellulose-, and polyester fiber-modified SMA mix exhibited high resistance and prevented bitumen from draining down [28,57].
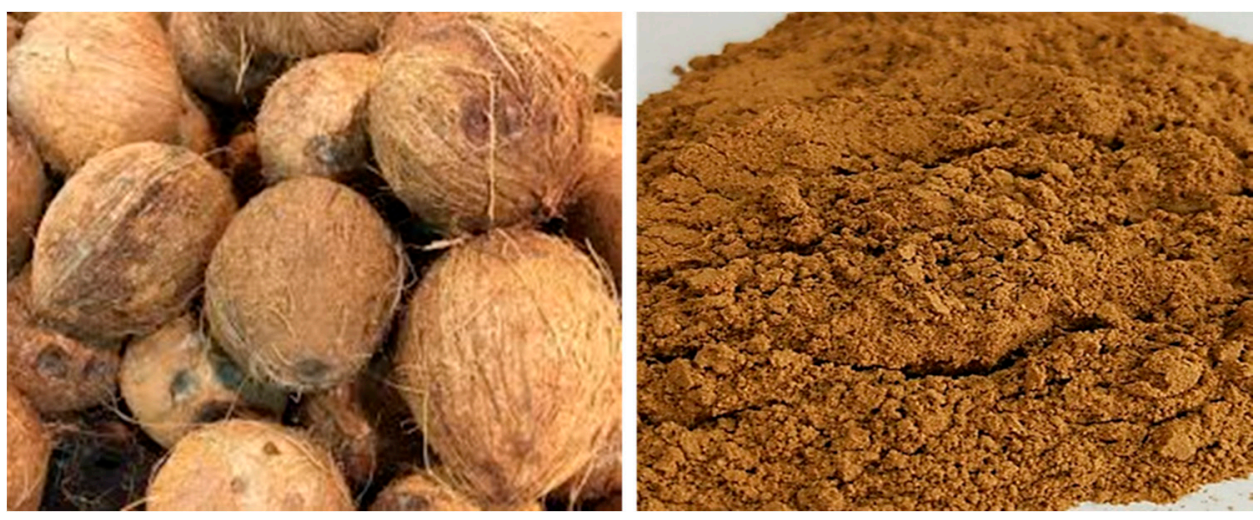

Figure 8. Coconut shell powder (on the right) produced from coconut (on the left), which can be used as fiber.

\subsection{Starch}

Starch (ST) is a natural polymer lighter in weight and is cheaper than other conventional synthetic polymers. Starch can be extracted from trees. Starch was blended with bitumen 70/100 paving grade bitumen. Modified binder was used to prepare stone mastic asphalt with calcium carbonate as a filler; physicochemical, alkali, acid, and fuel resistance tests were performed, as well as the Marshall stability, Marshall quotient, tensile strength, tensile strength ratio, flexural strength, rutting resistance, and resilient modulus tests. The result shows that ST-modified asphalt concrete performs better than conventional and styrene-butadiene block copolymer (SBS)-modified mixture, as shown in Figure 9. Rutting potential and temperature susceptibility can be reduced by the inclusion of ST in the asphalt mixture [58].

\subsection{Waste Glass}

Waste glass is generated globally, and mostly comes from glass containers for storage, windows, and windscreens of vehicles. Many research works have been carried out to recycle and reuse waste glass. Glass is a brittle material that mostly contains silica. The inclusion of crushed waste glass from car windscreens in standard asphalt mixtures with less than $5 \%$ bitumen resulted in improvements in the mechanical properties in asphalt concrete [59]. The study also found that when the percentage of crushed waste glass was less than or greater than $10 \%$, no further increase to the asphalt concrete's physical or mechanical properties was seen. Abu Salem and colleagues reported that the addition of waste glass from car windscreens into asphalt concrete had been implemented successfully in the United States since 1990 [60]. It should be noted that a limitation of this study is that fatigue testing 
was limited to speeds up to $65 \mathrm{~km} / \mathrm{h}$, while in real-world scenarios, cars often achieve speeds much higher than $65 \mathrm{~km} / \mathrm{h}$ on most free-flowing roads. The use of glass cullet as a filler in HMA mixtures has also been studied, and it has been shown that a mix with $6 \%$ bitumen content and $15 \%$ glass cullet content reduces the strain properties of asphalt concrete at $5^{\circ} \mathrm{C}, 25^{\circ} \mathrm{C}$, and $40{ }^{\circ} \mathrm{C}$ compared to the control sample [61].

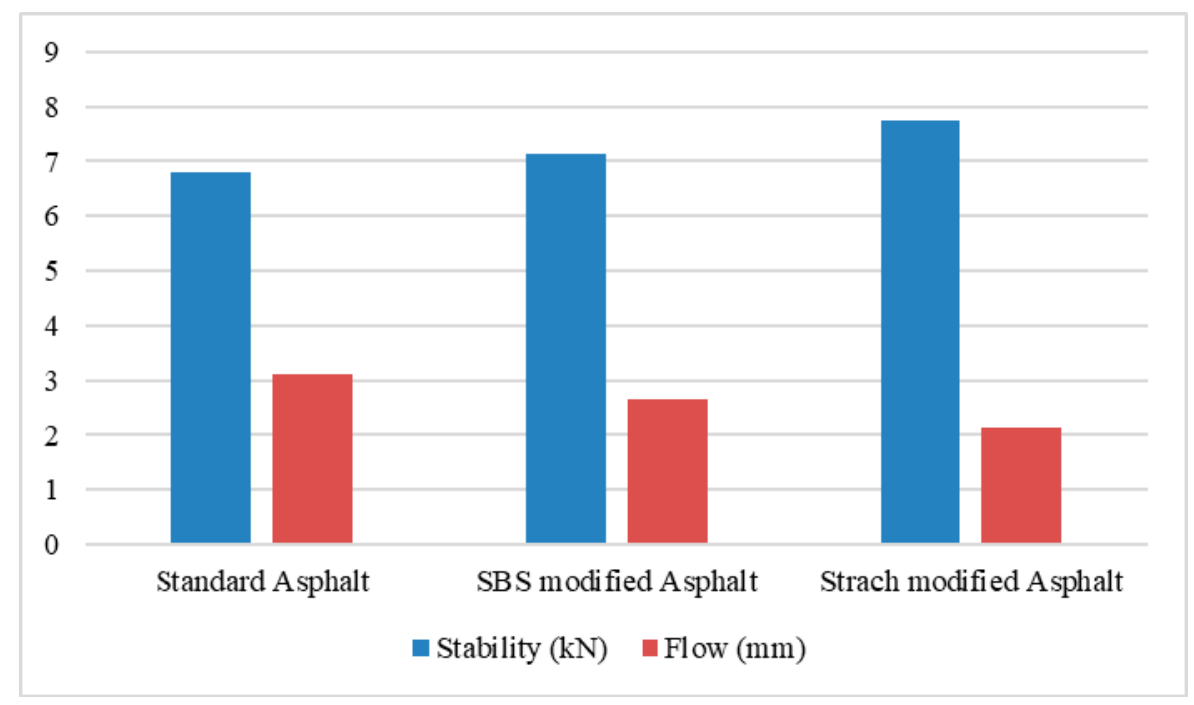

Figure 9. Marshall stability and flow test result of asphalt concrete modified with styrene-butadiene block copolymer (SBS) and starch [58].

The incorporation of crushed waste glass into asphalt concrete as a substitute for fine aggregates and a cementitious material with satisfactory results has been recently investigated. The study found that HMA mix properties could be improved with the implementation of crushed glass, even when $20 \%$ of fine aggregates were replaced with waste glass [62].

\subsection{Waste Brick}

Waste bricks are generated during the masonry work of construction. This waste brick can be utilized in soil stabilization and can be reused as fillers. The addition of pulverized waste brick as an alternative filler compared to mineral fibers has recently been studied, with positive results. It was apparent that the addition of crushed waste brick as a filler improved the mixture's mechanical properties at temperatures of $5{ }^{\circ} \mathrm{C}$ and $40{ }^{\circ} \mathrm{C}$ [63]. At both $5^{\circ} \mathrm{C}$ and $40{ }^{\circ} \mathrm{C}$, the mixtures displayed a higher indirect tensile modulus compared to the control sample, which used traditional mineral fillers. The study that investigated pulverized brick waste as a filler also showed promising results regarding the long-term durability of the asphalt, as water sensitivity testing displayed better results in the fatigue life of the concrete asphalt $[63,64]$.

In the state of Victoria, Australia alone, 300,000 tons of waste brick waste were recovered in 2009. However, it was found that reclaimed waste brick may contain up to $30 \%$ of other materials, such as concrete or rock [12]. Typical waste brick was found to be suitable in lower quality mixes, and brick with lower porosity levels displayed high compressive strength, allowing a higher quality mix to be manufactured [64].

\subsection{Waste Ceramics}

Waste ceramics are mostly generated during the interior work of a building structure. These wastes are thrown into the landfill as part of waste management. Recycling this widely generated heavy waste can reduce the burden on landfills. Pulverized waste ceramic materials have shown promising results for the use of secondary aggregates when used at 20\% of the weight of aggregates [65]. 
The results from the study indicated that the mix that contained more than $20 \%$ and less than $100 \%$ of the weight of aggregates displayed better mechanical properties compared to the control mix, which utilized limestone as an aggregate. Glazed tiles were excluded in this study, as the glazing applied to the ceramic material disallows proper binding of the HMA mixture. Rutting potential and fatigue testing were also excluded from this study. Research has been conducted to investigate the compatibility of ceramic waste material as a secondary aggregate and it was found that the ideal percentage of waste ceramic was 30\% of the weight of aggregates, as shown in Figure 10 [66].

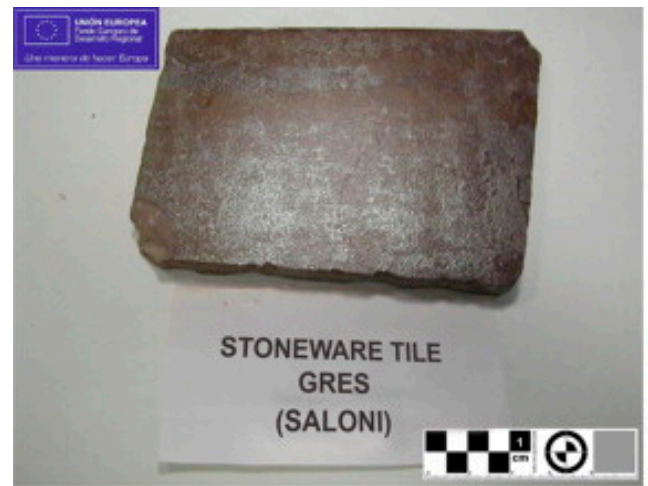

(a)

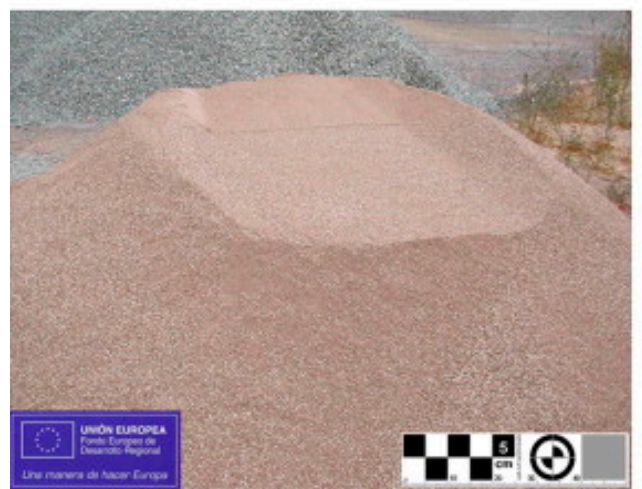

(c)

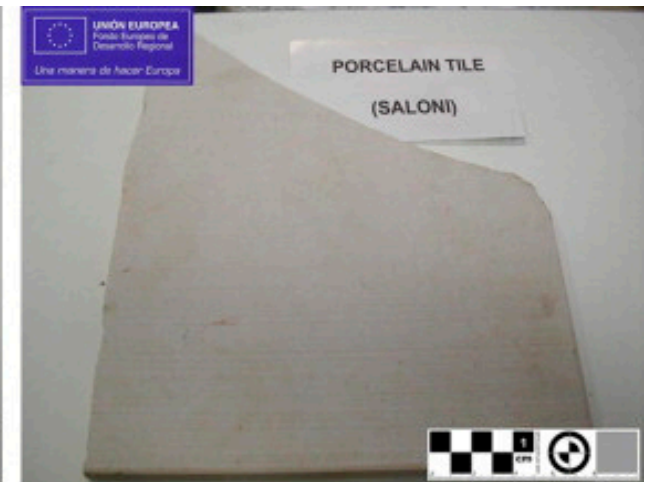

(b)

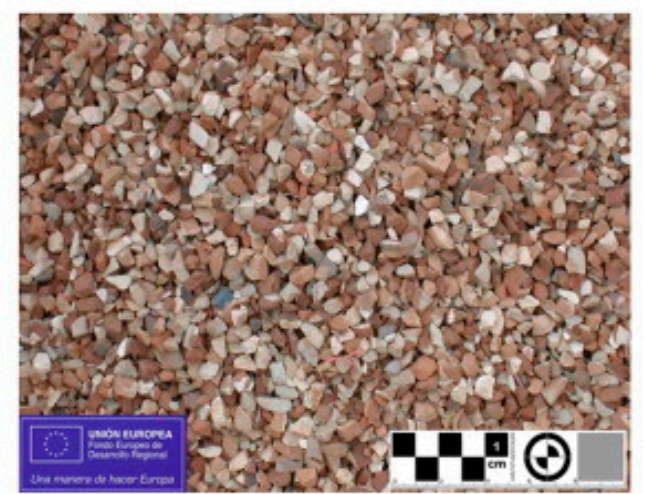

(d)

Figure 10. (a) Stoneware tile waste; (b) porcelain tile waste; (c) recycled ceramic aggregates ( $0-4 \mathrm{~mm}$ fine fraction); and (d) recycled ceramic aggregates (4-11 mm coarse fraction) [66].

\subsection{Waste Fly-ash}

Fly ash is mostly generated from coal-powered plants as a by-product. Waste fly-ash is one of Australia's biggest pollutants, with 6 million tons of waste fly-ash was produced in 2014 and 2015 [1]. The use of waste fly-ash generated from the paper industry has been studied in Spain, with less than satisfactory results. Fly ash was utilized as a filler rather than a secondary aggregate in HMA mixtures, resulting in a 7.8\% decrease in the resilient modulus, as shown in Figure 11 [67]. Furthermore, the resultant mixture was less stiff and less dense than the control sample. It was suggested that the implementation of fly ash into cold mix asphalt mixtures might provide more satisfactory results due to the fly ash containing hydrated lime. 


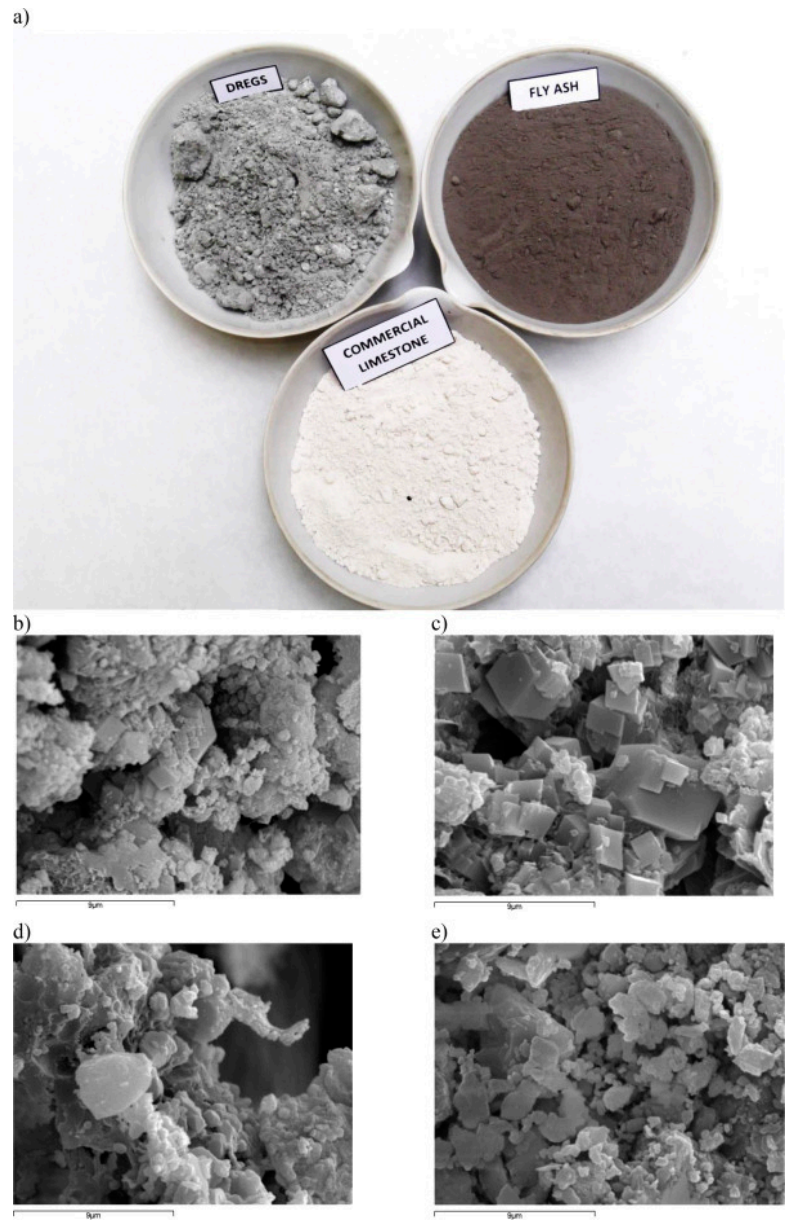

Figure 11. Pictures (a) and SEM pictures (b-e) of the three fillers: (a) dregs, fly ash, and commercial limestone; (b) dregs, (c) detail of cube-shaped crystals of dregs; (d) fly ash; and (e) commercial limestone [66].

However, a recent study by Mohammadinia et al. (2017), considered the suitability of fly-ash as a stabilizer in pavement base applications with positive results. The results displayed that a $15 \%$ fly-ash content was optimum for pavement binders [68].

\subsection{Cigarette Butts (CBs)}

Cigarette butts (CBs) are the bottom part of a cigarette. They are mostly made of cellulose acetate-based filter and paper [69]. CBs are common form of litter worldwide; hence a sustainable method to recycle CBs could reduce CB pollution problems [70]. Researchers are exploring different ways to recycle this waste to achieve sustainability and reduce the pollution caused by discarded cigarette butts. A recent study at RMIT University initiated by Mohajerani proved that CBs could also be recycled in asphalt concrete. Samples were prepared by the incorporation of encapsulated CBs in asphalt concrete. Figure 12 exhibits the bitumen encapsulated CBs, which were used to prepare asphalt samples. The physical and mechanical performance of the samples was propitious. Furthermore, this work has widened the scope of research for recycling cigarette butts (CBs) in asphalt concrete [71]. Asphalt samples were prepared with incorporation of CBs at $10 \mathrm{~kg} / \mathrm{m}^{3}, 15 \mathrm{~kg} / \mathrm{m}^{3}$, and $25 \mathrm{~kg} / \mathrm{m}^{3}$, and with no CBs (control samples). Some of the asphalt samples prepared for this breakthrough research are shown in Figure 13. The impact of different quantities of CBs in terms of Marshall stability and flow of asphalt sample where CBs were encapsulated with different classes of bitumen are shown in the Figure 14. 


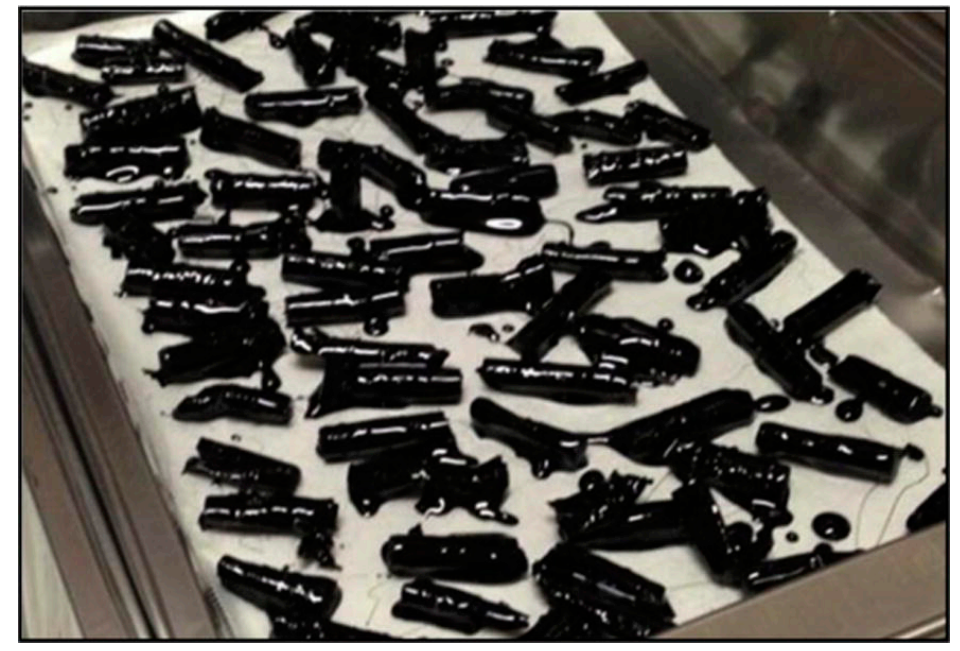

Figure 12. Encapsulated cigarette butts (CBs) used in the research conducted by Mohajerani et al. (2017) [71].

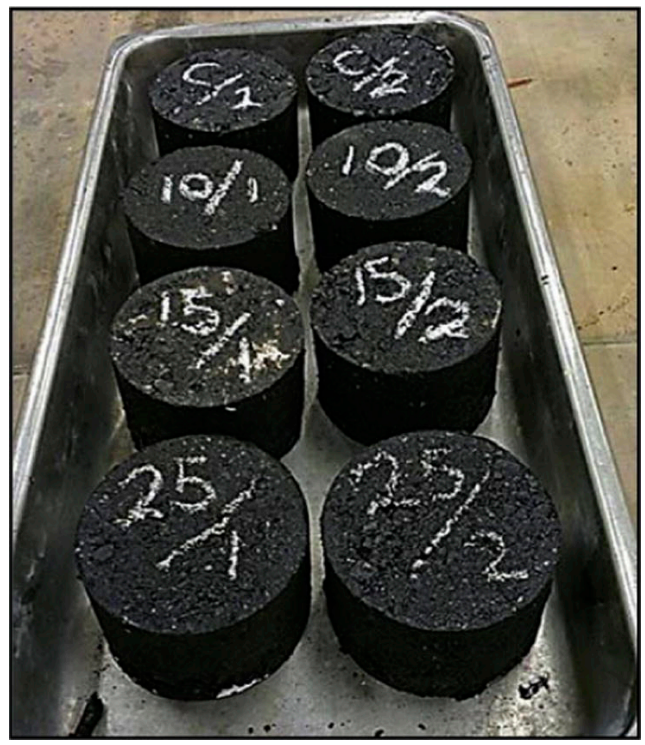

Figure 13. Some CB-modified asphalt samples prepared by Mohajerani et al. (2017) [71].

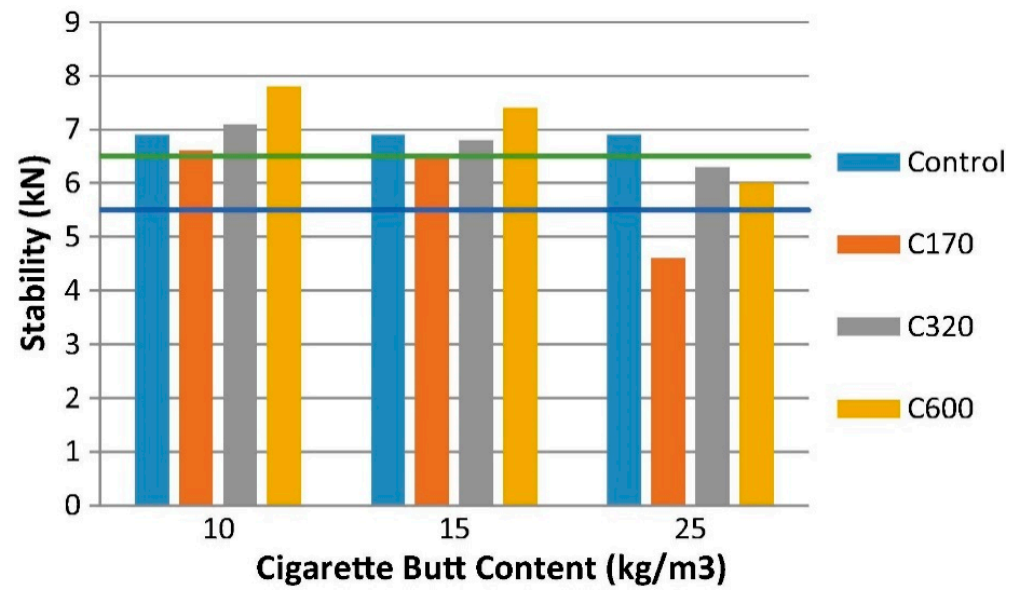

Figure 14. Marshall stability and flow of asphalt prepared with different amounts of CBs $(10 \mathrm{~kg}, 15 \mathrm{~kg}$, and $25 \mathrm{~kg}$ CBs in each $\mathrm{m}^{3}$ of dense asphalt) encapsulated with bitumen classes C170, C320, and C600 [71]. 
Mohajerani et al. (2017) assessed the resilient modulus of asphalt concrete prepared with CBs and found the all the samples met the standard range 2500-4000 MPa for bitumen class C170 [71]. The results are shown in Figure 15.

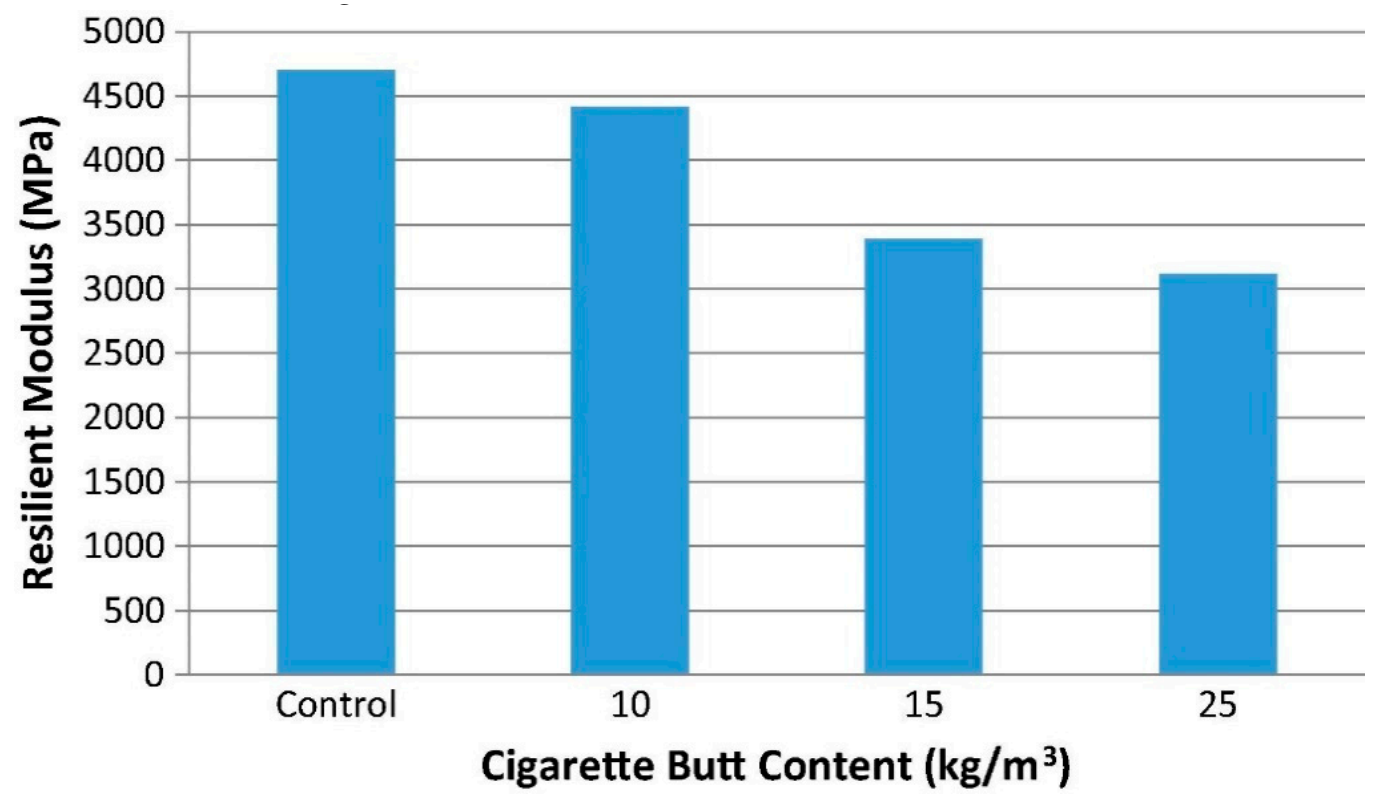

Figure 15. Resilient modulus of asphalt concrete $\left(10 \mathrm{~kg}, 15 \mathrm{~kg}\right.$, and $25 \mathrm{~kg}$ CBs in each $\mathrm{m}^{3}$ of dense asphalt) prepared with different amounts of bitumen class C170 encapsulated CBs [71].

Recent research showed that cigarette butts (CBs) could be recycled as fiber modifier in bitumen for the construction of asphalt concrete [36]. Different types of bitumen were blended with $0.2 \%-0.5 \%$ $\mathrm{CBs}$ as fiber. Results found that CBs as fiber in bitumen enhance the viscosity of the binder and turn the samples less susceptible to temperature change. Resistance to binder drain-off of $0.3 \% \mathrm{CB}$ fiber-modified bitumen has increased significantly [36].

\section{Significance of Recycling Waste Materials in Asphalt Concrete and Bitumen}

\subsection{Application}

Recycling waste materials in asphalt concrete can largely contribute to the sector of waste management. Roads and highways are the world's largest asset. In the United States, the length of the road network is approximately 6.58 million kilometers [72]. Australia has a road network length of over 832,000 kilometers, and China has a road network measuring more than 4.24 million kilometers [72]. If waste products can be successfully recycled in roads and highways, the global environmental pollution problem due to waste management will be reduced significantly. Asphalt concretes are not only being used in the construction of roads for vehicles but are also being used in the construction of walkways, bike paths, parking lots, and driveways. Bitumen is mostly used as a binder for asphalt concrete. However, bitumen has been used in waterproofing and roofing materials $[73,74]$. The use of waste materials as an additive can reduce the mixing temperature depending on the devised mixing method. This process can reduce the usage of fuel and minimize emissions [75]. Waste materials can be added to asphalt concrete and bitumen in different forms depending on the type of waste and characteristics. Table 4 summarizes all reviewed materials in asphalt concrete and bitumen. The use of the correct form (e.g., as aggregates, fillers, or modifiers) of waste materials in asphalt concrete and bitumen is important to maintain industry standard performance. 
Table 4. Summary of the use of waste materials in asphalt concrete and bitumen.

\begin{tabular}{|c|c|c|c|c|}
\hline Type of Material & $\begin{array}{l}\text { Possible Recycling in } \\
\text { Asphalt Concrete }\end{array}$ & $\begin{array}{l}\text { Performance In Asphalt } \\
\text { Concrete }\end{array}$ & $\begin{array}{l}\text { Possible Recycling in } \\
\text { Bitumen }\end{array}$ & $\begin{array}{l}\text { Performance in } \\
\text { Bitumen }\end{array}$ \\
\hline Plastic & As aggregate & Improved Marshall stability & As a binder modifier & $\begin{array}{l}\text { Improved resistance to } \\
\text { permanent deformation }\end{array}$ \\
\hline Glass & As aggregate & Reduced Marshall stability & - & - \\
\hline Quarry waste & As aggregate & Suitable for low-traffic roads & - & - \\
\hline $\begin{array}{l}\text { Building demolition } \\
\text { waste }\end{array}$ & As aggregate & Met standard requirement & - & - \\
\hline Ground tire rubber & As additive & Improved rutting resistance & As a binder modifier & $\begin{array}{l}\text { Improved binder drain } \\
\text { of resistance and } \\
\text { high-temperature } \\
\text { properties }\end{array}$ \\
\hline Waste cooking oil & - & - & As a binder modifier & Improved viscosity \\
\hline Starch & - & - & As a binder modifier & $\begin{array}{l}\text { Reduced rutting } \\
\text { potential and } \\
\text { temperature } \\
\text { susceptibility }\end{array}$ \\
\hline Waste brick & As filler & $\begin{array}{l}\text { Improved durability and } \\
\text { resistance to fatigue }\end{array}$ & - & - \\
\hline Waste ceramic & As aggregate & $\begin{array}{l}\text { Improved mechanical } \\
\text { properties }\end{array}$ & - & - \\
\hline Fly ash & As filler & $\begin{array}{l}\text { Reduced resilient modulus } \\
\text { in hot mix asphalt }\end{array}$ & - & - \\
\hline
\end{tabular}

\subsection{Economic and Environmental Aspect}

Sustainability can be ensured in recycling waste if the final product performs to the same degree or better than the existing product at a low cost and, at the same time, entails some environmental benefit (e.g., low emissions, less landfill use). The use of waste materials in asphalt concrete and bitumen presents a prominent prospect of managing those waste sustainably. Plastic and polymer-based waste products are abandoned everywhere. The use of plastic in asphalt is still in its primary stage. However, the use of polymer-modified bitumen has already gained industry attention. The use of polymer-modified bitumen (PMB) in stone mastic asphalt has become common practice. This paved a way to recycle polymers sustainably and introduced an improved binder for the construction of asphalt concretes. Quarry waste has significant prospects in terms of economic and environmental uses. These waste materials can be utilized as conventional aggregates, which will facilitate efficient management of quarry waste. Both developing and developed cities are generating more building demolition waste every day. Where countries are densely populated and there is a scarcity of livable land areas, minimizing landfill areas can contribute largely to the socio-economic outcome. Utilizing building demolition waste in asphalt concrete significantly reduces the usage of landfills. Ground tire rubber has the potential to be used in asphalt concrete and bitumen. This waste provides a low-cost solution both as an additive and binder modifier. The use of waste cooking oil in asphalt is still in the preliminary research stage. However, this method provides a solution for recycling waste cooking oil in an environmentally friendly manner. Different types of waste fiber can be recycled in asphalt concrete and contribute to sustainable practice. The use of cellulose fiber has become industry practice for the construction of stone mastic asphalt. Waste glass can be used effectively as a filler in asphalt concrete. Crushed glass was successfully utilized during the Tullamarine Freeway widening in Victoria, Australia [76]. Waste ceramic and bricks can be used as aggregates in asphalt concrete. Conventional aggregates are obtained by blasting natural rock, which creates an environmental issue as natural 
resources are limited. Used of waste in alternative aggregates and modifiers can reduce the use of natural aggregates and give a second life to waste materials. The use of cigarette butts in asphalt concrete is a very recent concept. The successful incorporation of cigarette butts in asphalt at the industry scale can contribute largely to solving global cigarette butt pollution problems.

\section{Conclusions}

The revolution of advanced materials has brought a new dimension to the pavement industry. New methods and procedures have been introduced to ensure the sustainability and efficiency of the roads. Research work is ongoing to investigate the suitability of different types of waste for incorporation as road construction materials. Materials like polymer and plastic have shown increased Marshall stability and flow. In past research, plastic was incorporated in the binder and improved rutting and fatigue performance. Waste from quarries provides a way to replace conventional aggregates for medium traffic conditions. The use of building demolition waste in the base and sub-base layers of asphalt concrete reduced pollution and gave a second life to the materials. Tire rubber powder has been used in many research and improved high-temperature properties. Waste cooking oil along with palm oil fuel ash helped in replacing up to $5 \%$ of conventional bitumen binder for asphalt concrete. Fiber-based waste like coconut, sisal, and cellulose prevented drain-down of bitumen and improved resilient modulus. Asphalt binder modified with starch performed better than the binder modified with SBS. Waste glass, bricks, and ceramics have been used as alternative aggregates and exhibited better mechanical properties. Fly ash has been used as filler in asphalt concrete, and the result showed the potential of fly ash into cold mix asphalt mixture. The use of bitumen with encapsulated cigarette butts in asphalt concrete is a new method of managing waste, which will lead to sustainable waste management with improved asphalt concrete.

\section{Recommendations and Scope for Further Research}

Recycling waste products for use in alternative construction materials may not only be a viable answer for the world's landfill use problem, but also presents a possibility for strengthening the mix design of asphalt concrete and bitumen. Although the use of these materials may initially increase the price of production, it is reasonable to conclude that the cost of recycling materials will reduce and become appropriate once it has become a common industry practice. Utilization of various types of waste in asphalt concrete and bitumen can ensure sustainability and establish innovative recycling procedures. This revolutionary concept can help save the environment from pollution and help in managing waste. All these materials discussed here are part of very recent research work, whereby most of the cases met requirements and exhibited similar behaviors in laboratory investigations as compared to standard asphalt concrete samples. Knowledge in this sector will help future researchers to identify areas for further study and proper guidelines to follow to achieve success. Sustainability and waste management are critical issues. Advances in the waste management sector and turning pollution into the solution will encourage sustainability and innovation in construction materials. Advanced materials will be introduced into the industry, and unique methods of characterization and analysis of the materials will emerge.

Author Contributions: Conceptualization: A.M., M.T.R.; Supervision: A.M.; Research design: M.T.R., A.M.; Review analysis: M.T.R.; Writing: M.T.R.; Editing and Reviewing: A.M.; Reviewing and Support: F.G. All authors have read and agreed to the published version of the manuscript.

Funding: This research received no external funding.

Acknowledgments: This work is part of an ongoing postgraduate study on recycling cigarette butts in asphalt concrete. The authors would like to thank Butt-Out Australia Pty Ltd., RMIT University, and the Australian Government Research Training Program (RTP) scholarship for their financial and in-kind support.

Conflicts of Interest: The authors declare no conflict of interest. 


\section{References}

1. Pickin, J.; Randell, P. Australian National Waste Report 2016. $2016 . \quad$ Available online: https://www.environment.gov.au/system/files/resources/d075c9bc-45b3-4ac0-a8f2-6494c7d1fa0d/ files/national-waste-report-2016.pdf (accessed on 25 March 2020).

2. Australian Bureau of Statistics. Waste. 2007. Available online: https://www.abs.gov.au/ausstats/abs@.nsf/ Lookup/by\%20Subject/1370.0 \{\}2010 \{\}Chapter \{\}Landfill\%20(6.6.4) (accessed on 25 March 2020).

3. Batayneh, M.; Marie, I.; Asi, I. Use of selected waste materials in concrete mixes. Waste Manag. 2007, 27, 1870-1876. [CrossRef] [PubMed]

4. Bolden, J.; Abu-Lebdeh, T.; Fini, E. Utilization of recycled and waste materials in various construction applications. Am. J. Environ. Sci. 2013, 9, 14-24. [CrossRef]

5. Cremiato, R.; Mastellone, M.L.; Tagliaferri, C.; Zaccariello, L.; Lettieri, P. Environmental impact of municipal solid waste management using Life Cycle Assessment: The effect of anaerobic digestion, materials recovery and secondary fuels production. Renew. Energy 2018, 124, 180-188. [CrossRef]

6. Kuhlman, T.; Farrington, J. What is sustainability? Sustainability 2010, 2, 3436-3448. [CrossRef]

7. Aziz, M.M.A.; Rahman, M.T.; Hainin, M.R.; Bakar WA, W.A. An overview on alternative binders for flexible pavement. Constr. Build. Mater. 2015, 84, 315-319. [CrossRef]

8. Abu-Lebdeh, T.; Hamoush, S.; Heard, W.; Zornig, B. Effect of matrix strength on pullout behavior of steel fiber reinforced very-high strength concrete composites. Constr. Build. Mater. 2011, 25, 39-46. [CrossRef]

9. James, M.N.; Choi, W.; Abu-Lebdeh, T. Use of recycled aggregate and fly ash in concrete pavement. Am. J. Eng. Appl. Sci. 2011, 4, 201-208. [CrossRef]

10. Hamoush, S.; Abu-Lebdeh, T.; Picornell, M.; Amer, S. Development of sustainable engineered stone cladding for toughness, durability, and energy conservation. Constr. Build. Mater. 2011, 25, 4006-4016. [CrossRef]

11. Anderson, D.; Youtcheff, J.; Zupanick, M. Asphalt Binders. In Transportation in the New Millennium; Transportation Research Board: Washington, DC, USA, 2000; Available online: http://onlinepubs.trb.org/ Onlinepubs/millennium/00006.pdf (accessed on 25 March 2020).

12. Asphalt Magazine. Asphalt is the pavement of choice in Australia. 2018. Available online: http:// asphaltmagazine.com/asphalt-is-the-pavement-of-choice-in-australia/ (accessed on 25 March 2020).

13. Trading Economics. Australia-Roads, Paved (\% of total roads). 2009. Available online: https://tradingeconomics.com/australia/roads-paved-percent-of-total-roads-wb-data.html (accessed on 25 March 2020).

14. Tayabji, S.D.; Brown, J.L.; Mack, J.W.; Hearne, T.M., Jr.; Anderson, J.O.H.N.; Murrell, S.C.O.T.T.; Noureldin, A.S. Pavement Rehabilitation. TRB Committee on Pavement Rehabilitation, TRB Millennium Paper Series. 2000. Available online: http://onlinepubs.trb.org/Onlinepubs/millennium/00086.pdf (accessed on 25 March 2020).

15. Mashaan, N.S.; Ali, A.H.; Karim, M.R.; Abdelaziz, M. A review on using crumb rubber in reinforcement of asphalt pavement. Sci. World J. 2014. [CrossRef]

16. Garcia, J.; Hansen, K. HMA Mix Type Selection Guide. Information Series 128; National Asphalt Pavement Association: Lanham, MD, USA, 2001.

17. Pavement Interactive. HMA Pavement. [cited 2018 25/06]. 2012. Available online: http://www. pavementinteractive.org/hma-pavement/ (accessed on 25 March 2020).

18. Blazejowski, K. Stone Matrix Asphalt: Theory and Practice; CRC Press: Boca Raton, FL, USA, 2016; Available online: http://sirjannano.com/Admin/upload/files/fani-nano/Binder1.pdf (accessed on 25 March 2020).

19. Shafabakhsh, G.H.; Sajed, Y. Investigation of dynamic behavior of hot mix asphalt containing waste materials; case study: Glass cullet. Case Stud. Constr. Mater. 2014, 1, 96-103. [CrossRef]

20. Sehgal, S.K. Stone Matrix Asphalt Indian Experiences. [cited 2019 24th March]. 2017. Available online: https://www.nbmcw.com/tech-articles/roads-and-pavements/36144-stone-matrix-asphalt-indianexperiences.html (accessed on 25 March 2020).

21. Rahman, M.T.; Aziz, M.M.A.; Hainin, M.R.; Bakar, W.A. Impact of bitumen binder: Scope of bio-based binder for construction of flexible pavement. J. Technol. 2014, 70, 105-109. [CrossRef]

22. John Rebbechi, L.P. Guide to Pavement Technology Part 4B: Asphalt; Austroads Ltd.: Sydney, Australia, 2014.

23. Rahman, M.T.; Hainin, M.R.; Bakar, W.A.W.A. Use of waste cooking oil, tire rubber powder and palm oil fuel ash in partial replacement of bitumen. Constr. Build. Mater. 2017, 150, 95-104. [CrossRef] 
24. Kalantar, Z.N.; Karim, M.R.; Mahrez, A. A review of using waste and virgin polymer in pavement. Constr. Build. Mater. 2012, 33, 55-62. [CrossRef]

25. Hunter, R.N.; Self, A.; Read, J. The Shell Bitumen Handbook; ICE Publishing: Westminster, UK, 2015.

26. Azahar, W.N.A.W.; Bujang, M.; Jaya, R.P.; Hainin, M.R.; Mohamed, A.; Ngad, N.; Jayanti, D.S. The potential of waste cooking oil as bio-asphalt for alternative binder-An overview. J. Technol. 2016, 78, 111-116.

27. Hainin, M.R.; Jaya, R.P.; Ali Akbar, N.A.; Jayanti, D.S.; Yusoff NI, M. Influence of palm oil fuel ash as a modifier on bitumen to improve aging resistance. J. Eng. Res. 2014, 2, 34-46.

28. Rusbintardjo, G.; Hainin, M.R.; Yusoff, N.I.M. Fundamental and rheological properties of oil palm fruit ash modified bitumen. Constr. Build. Mater. 2013, 49, 702-711. [CrossRef]

29. Mohajerani, A.; Hui, S.Q.; Mirzababaei, M.; Arulrajah, A.; Horpibulsuk, S.; Abdul Kadir, A.; Rahman, M.T.; Maghool, F. Amazing Types, Properties, and Applications of Fibres in Construction Materials. Materials 2019, 12, 2513. [CrossRef]

30. Poulikakos, L.D.; Papadaskalopoulou, C.; Hofko, B.; Gschösser, F.; Falchetto, A.C.; Bueno, M.; Loizidou, M. Harvesting the unexplored potential of European waste materials for road construction. Resour. Conserv. Recycl. 2017, 116, 32-44. [CrossRef]

31. Hu, C.; Lin, W.; Partl, M.; Wang, D.; Yu, H.; Zhang, Z. Waste packaging tape as a novel bitumen modifier for hot-mix asphalt. Constr. Build. Mater. 2018, 193, 23-31. [CrossRef]

32. Razali, M.N.; Aziz, M.A.A.; Jamin, N.F.M.; Salehan, N.A.M. Modification of bitumen using polyacrylic wig waste. AIP Conf. Proc. 2018. [CrossRef]

33. Liu, X.; Wu, S. Study on the graphite and carbon fiber modified asphalt concrete. Constr. Build. Mater. 2011, 25, 1807-1811. [CrossRef]

34. Serin, S.; Morova, N.; Saltan, M.; Terzi, S. Investigation of usability of steel fibers in asphalt concrete mixtures. Constr. Build. Mater. 2012, 36, 238-244. [CrossRef]

35. VicRoads. SECTION 404-STONE MASTIC ASPHALT. Australia; 2012. Available online: http: //webapps.vicroads.vic.gov.au/VRNE/csdspeci.nsf/webscdocs/5916DDA1FE3D3096CA2579E4001945FB/ \$File/Sec404.doc (accessed on 25 March 2020).

36. Toraldo, E.; Mariani, E.; Malvicini, S. Laboratory investigation into the effects of fibers on bituminous mixtures. J. Civ. Eng. Manag. 2015, 21, 45-53. [CrossRef]

37. Rahman, M.T.; Mohajerani, A.; Giustozzi, F. Possible Recycling of Cigarette Butts as Fiber Modifier in Bitumen for Asphalt Concrete. Materials 2020, 13, 734. [CrossRef] [PubMed]

38. Hınıslıoğlu, S.; Ağar, E. Use of waste high density polyethylene as bitumen modifier in asphalt concrete mix. Mater. Lett. 2004, 58, 267-271. [CrossRef]

39. Dalhat, M.A.; Al-Abdul Wahhab, H.I. Performance of recycled plastic waste modified asphalt binder in Saudi Arabia. Int. J. Pavement Eng. 2017, 18, 349-357. [CrossRef]

40. Becker, Y.; Mendez, M.P.; Rodriguez, Y. Polymer modified asphalt. Vis. Technol. 2001, 9, 39-50.

41. Azarhoosh, A.R.; Hamedi, G.H.; Abandansari, H.F. Providing Laboratory Rutting Models for Modified Asphalt Mixes with Different Waste Materials. Period. Polytech. Civ. Eng. 2018, 62, 308-317. [CrossRef]

42. Al-Salem, S.M.; Lettieri, P.; Baeyens, J. Recycling and recovery routes of plastic solid waste (PSW): A review. Waste Manag. 2009, 29, 2625-2643. [CrossRef]

43. Ahmadinia, E.; Zargar, M.; Karim, M.R.; Abdelaziz, M.; Shafigh, P. Using waste plastic bottles as additive for stone mastic asphalt. Mater. Des. 2011, 32, 4844-4849. [CrossRef]

44. Zakaria, N.M.; Hassan, M.K.; Ibrahim AN, H.; Rosyidi SA, P.; Yusoff NI, M.; Mohamed, A.A.; Hassan, N. The use of mixed waste recycled plastic and glass as an aggregate replacement in asphalt mixtures. J. Technol. 2018, 80, 79-88. [CrossRef]

45. Akbulut, H.; Gürer, C. Use of aggregates produced from marble quarry waste in asphalt pavements. Build. Environ. 2007, 42, 1921-1930. [CrossRef]

46. Gautam, P.K.; Kalla, P.; Nagar, R.; Agrawal, R.; Jethoo, A.S. Laboratory investigations on hot mix asphalt containing mining waste as aggregates. Constr. Build. Mater. 2018, 168, 143-152. [CrossRef]

47. Aljassar, A.H.; Al-Fadala, K.B.; Ali, M.A. Recycling building demolition waste in hot-mix asphalt concrete: A case study in Kuwait. J. Mater. Cycles Waste Manag. 2005, 7, 112-115. [CrossRef]

48. Tavira, J.; Jiménez, J.R.; Ayuso, J.; Sierra, M.J.; Ledesma, E.F. Functional and structural parameters of a paved road section constructed with mixed recycled aggregates from non-selected construction and demolition waste with excavation soil. Constr. Build. Mater. 2018, 164, 57-69. [CrossRef] 
49. Blengini, G.A. Life cycle of buildings, demolition and recycling potential: A case study in Turin, Italy. Build. Environ. 2009, 44, 319-330. [CrossRef]

50. Chiu, C.T.; Lu, L.C. A laboratory study on stone matrix asphalt using ground tire rubber. Constr. Build. Mater. 2007, 21, 1027-1033. [CrossRef]

51. Behnood, A.; Olek, J. Rheological properties of asphalt binders modified with styrene-butadiene-styrene (SBS), ground tire rubber (GTR), or polyphosphoric acid (PPA). Constr. Build. Mater. 2017, 151, 464-478. [CrossRef]

52. Aoudia, K.; Azem, S.; Hocine, N.A.; Gratton, M.; Pettarin, V.; Seghar, S. Recycling of waste tire rubber: Microwave devulcanization and incorporation in a thermoset resin. Waste Manag. 2017, 60, 471-481. [CrossRef]

53. Pouranian, M.R.; Notani, M.A.; Tabesh, M.T.; Nazeri, B.; Shishehbor, M. Rheological and environmental characteristics of crumb rubber asphalt binders containing non-foaming warm mix asphalt additives. Constr. Build. Mater. 2020, 238, 117707. [CrossRef]

54. Ding, X.; Chen, L.; Ma, T.; Ma, H.; Gu, L.; Chen, T.; Ma, Y. Laboratory investigation of the recycled asphalt concrete with stable crumb rubber asphalt binder. Constr. Build. Mater. 2019, 203, 552-557. [CrossRef]

55. Mohajerani, A.; Burnett, L.; Smith, J.V.; Markovski, S.; Rodwell, G.; Rahman, M.T.; Kurmus, H.; Mirzababaei, M.; Arulrajah, A.; Horpibulsuk, S.; et al. Recycling waste rubber tyres in construction materials and associated environmental considerations: A review. Resour. Conserv. Recycl. 2020, 155, 104679. [CrossRef]

56. Ting, T.L.; Jaya, R.P.; Hassan, N.A.; Yaacob, H. Resilient modulus of double layer porous asphalt: Application of alkali treated coconut shell and fiber as aggregate replacement. Malays. J. Civ. Eng. 2017, 29, 187-194.

57. Agunsoye, J.O.; Bello, S.A.; Azeez, S.O.; Yekinni, A.A.; Adeyemo, R.G. Recycled polypropylene reinforced coconut shell composite: Surface treatment morphological, mechanical and thermal studies. Int. J. Compos. Mater. 2014, 4, 168-178.

58. Oda, S.; Fernandes Jr, J.L.; Ildefonso, J.S. Analysis of use of natural fibers and asphalt rubber binder in discontinuous asphalt mixtures. Constr. Build. Mater. 2012, 26, 13-20. [CrossRef]

59. Al-Hadidy, A.I.; Yi-Qiu, T.; Hameed, A.T. Starch as a modifier for asphalt paving materials. Constr. Build. Mater. 2011, 25, 14-20.

60. Issa, Y. Effect of adding crushed glass to asphalt mix. Arch. Civil Eng. 2016, 62, 35-44. [CrossRef]

61. Salem, Z.T.A.; Khedawi, T.S.; Baker, M.B.; Abendeh, R. Effect of waste glass on properties of asphalt concrete mixtures. Jordan J. Civ. Eng. 2017, 11, 117-131.

62. Mohajerani, A.; Vajna, J.; Cheung TH, H.; Kurmus, H.; Arulrajah, A.; Horpibulsuk, S. Practical recycling applications of crushed waste glass in construction materials: A review. Constr. Build. Mater. 2017, 156, 443-467. [CrossRef]

63. Chen, M.Z.; Lin, J.T.; Wu, S.P.; Liu, C.H. Utilization of recycled brick powder as alternative filler in asphalt mixture. Constr. Build. Mater. 2011, 25, 1532-1536. [CrossRef]

64. Arulrajah, A.; Piratheepan, J.; Aatheesan, T.; Bo, M.W. Geotechnical properties of recycled crushed brick in pavement applications. J. Mater. Civ. Eng. 2011, 23, 1444-1452. [CrossRef]

65. Muniandy, R.; Ismail, D.H.; Hassim, S. Performance of recycled ceramic waste as aggregates in hot mix asphalt (HMA). J. Mater. Cycles Waste Manag. 2018, 20, 844-849. [CrossRef]

66. Silvestre, R.; Medel, E.; García, A.; Navas, J. Using ceramic wastes from tile industry as a partial substitute of natural aggregates in hot mix asphalt binder courses. Constr. Build. Mater. 2013, 45, 115-122. [CrossRef]

67. Pasandín, A.R.; Pérez, I.; Ramírez, A.; Cano, M.M. Moisture damage resistance of hot-mix asphalt made with paper industry wastes as filler. J. Clean. Prod. 2016, 112, 853-862. [CrossRef]

68. Mohammadinia, A.; Arulrajah, A.; Horpibulsuk, S.; Chinkulkijniwat, A. Effect of fly ash on properties of crushed brick and reclaimed asphalt in pavement base/subbase applications. J. Hazard. Mater. 2017, 321, 547-556. [CrossRef] [PubMed]

69. Mohajerani, A.; Kadir, A.A.; Larobina, L. A practical proposal for solving the world's cigarette butt problem: Recycling in fired clay bricks. Waste Manag. 2016, 52, 228-244. [CrossRef]

70. Truth Initiative. 5 Ways Cigarette Litter Impacts the Environment. [cited 201910 January]. 2017. Available online: https://truthinitiative.org/news/5-ways-cigarette-litter-impacts-environment (accessed on 25 March 2020). 
71. Mohajerani, A.; Tanriverdi, Y.; Nguyen, B.T.; Wong, K.K.; Dissanayake, H.N.; Johnson, L.; Whitfield, D.; Thomson, G.; Alqattan, E.; Rezaei, A. Physico-mechanical properties of asphalt concrete incorporated with encapsulated cigarette butts. Constr. Build. Mater. 2017, 153, 69-80. [CrossRef]

72. Road Traffic Technology The World's Biggest Road Networks. [cited 2020 10th March]. 2014. Available online: https://www.roadtraffic-technology.com/features/featurethe-worlds-biggest-road-networks-4159235/ (accessed on 25 March 2020).

73. De Brimont, M.R.; Hörnig, A.; JENSEN, E.S.; Olsen, J.E. Lightweight filler for waterproofing bitumen membranes. U.S. Patent Application No. 16/331,174, 22 August 2019.

74. Smith, J.D.; Mellott, I.J.W.; Rus, M.; Sokol, D.; Holland, J. Active polymer modification of bitumen for use in roofing materials. U.S. Patent Application No. 16/245,684, 29 August 2017.

75. Pouranian, M.R.; Shishehbor, M. Sustainability assessment of green asphalt mixtures: A review. Environments 2019, 6, 73. [CrossRef]

76. Cuthbertson, D. 'Have a crack at it': Glass Plant to Recycle a Billion Bottles a Year, The Age. Australia. Published on 31st March 2019. 2019. Available online: https://www.theage.com.au/national/victoria/have-acrack-at-it-glass-plant-to-recycle-a-billion-bottles-a-year-20190531-p51t7c.html (accessed on 25 March 2020).

(C) 2020 by the authors. Licensee MDPI, Basel, Switzerland. This article is an open access article distributed under the terms and conditions of the Creative Commons Attribution (CC BY) license (http://creativecommons.org/licenses/by/4.0/). 